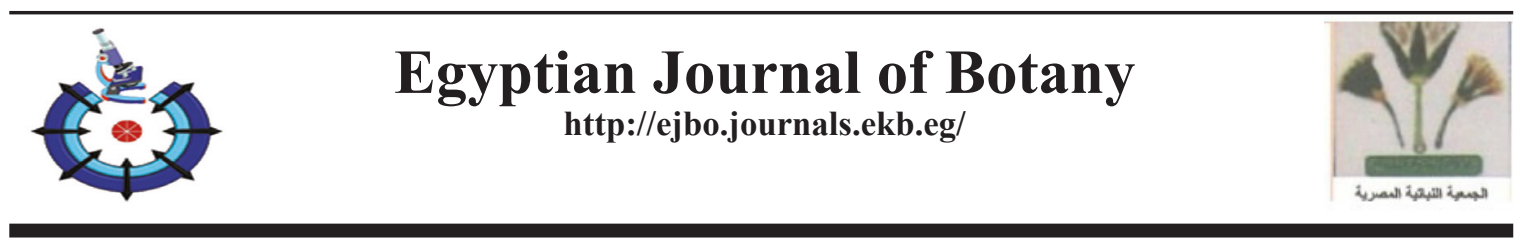

\title{
Improving Wastewater Treatment Using Dried Banana Leaves and Bacteriophage Cocktail
}

\author{
Noha K. El-Dougdoug(1)\#, M.A. Nasr-Eldin ${ }^{(1)}$, M.I. Azzam ${ }^{(2)}$, Aya A. Mohamed(1), \\ M.M. Hazaa ${ }^{(1)}$ \\ (1)Botany and Microbiology Department, Faculty of Science, Benha University, \\ Benha, Egypt; (2) Central Lab for Environmental Quality Monitoring, National Water \\ Research Center, Cairo, Egypt.
}

\begin{abstract}
W ATER pollution is a serious problem resulting from introduction of hazardous biological waste, organic materials and heavy metals into the natural environment. This study aimed for improving the quality of wastewater as measured by the physicochemical parameters and controlling microbial pollution using dried banana leaves with phage cocktail. Different wastewater samples were collected from New Cairo, Gabal El-Asfar and Helwan, Egypt, and were used for isolation of Escherichia coli, Pseudomonas aeruginosa and Salmonella Typhi and their specific phages. Fine dried powder of banana leaves was prepared to improve the physicochemical characteristics and reduce microbial populations; the treatment of wastewater was performed using fine powder of banana leaves, phage cocktail individually and in combination. Before treatment, the physical and chemical parameters showed higher levels, dissolved oxygen was depleted and the counts of total coliforms, fecal coliforms and fecal streptococci exceeded the permissible limits. However, using banana leaves, there was an improvement in physicochemical parameters and slight reduction of bacterial populations. Individual application of phage cocktail resulted in a significant reduction of bacterial growth as well as adsorption of wastewater pollutants. Furthermore, using combination of phage cocktail specific to E. coli, $P$. aeruginosa and $S$. Typhi and fine powder of banana leaves enhanced the microbial inactivation and removal of water pollutants. Thus, this study indicated the capability of using ecofriendly approach comprising of fine dried powder banana leaves and phage cocktail for wastewater treatment and paves the way for further research to enable reusing wastewater.
\end{abstract}

Keywords: Banana leaves, Bio adsorption, Phages, Pollution, Treatment, Wastewater.

\section{Introduction}

Water is one of the main forms of our life and it is a natural resource for all living organisms. It has various uses including household works, agriculture and industrial purposes (Chaurasia \& Pandey, 2007; Usharani et al., 2010; Rathore et al., 2014). In recent days, the pollution of water became a serious problem in developing countries and all over the world due to uncontrolled urbanization that threats the life on the earth due to sewage effluent discharged into water sources (Tamil et al., 2012; Ouf et al., 2018). All recent trends try to find solutions for environmental management, prevention of pollution, treatment and recycling of wastes for reusing the wastewater (Azab, 2008; El-Sayed et al., 2015).

The world health organization (WHO) reported that inadequate water sanitation and hygiene practices have a great effect on the death rates each year. In addition, the high risk of human health is due to pathogenic microbes in water contaminated by human and animal feces (Shannon et al., 2007, WHO, 2011; Novo et al., 2013).

\#Corresponding author email: nohaeldougdoug@gmail.com

Received 24/2/2019; Accepted 8/9/2019

DOI: $110.21608 /$ ejbo.2019.7597.1295

Edited by: Dr. Mahmoud S.M. Mohamed, Faculty of Science, Cairo University, Giza, Egypt.

(C)2020 National Information and Documentation Center (NIDOC) 
Bioremediation, a trend to break down and consume pollutants from environment, has been used with varying degrees of success (Vasconcellos, 2009; Ravi et al., 2013). It involves microbial cleanup of environmental pollutants without disruption to the local environment (Vezzulli et al., 2004). Bacteriophages with lytic activity are a novel tool for controlling bacterial pathogens (El-Dougdoug et al., 2019). In addition to that, using phage cocktail has a great effect in bio-desorption, bioremediation of pollutants and recycling of wastewater (Gaikwad et al., 2014; Zhao et al., 2009).

Using plant extract is considered an ecofriendly and effective way to eliminate pollutants from water. The banana leaves act as bio-adsorbent agent that pick up large amounts of pollutants, metals and pathogens from wastewater. They have a significant effect on the availability of metals (Sankaravelu et al., 2016; Giorgio et al., 2017). Furthermore, the banana leaves have an effect on the microbial community in waste water. That was attributed to the inhibitory effect mediated by phenolic compounds on bacterial pathogens. Recently, global concern is heading to find ways for controlling environmental pollutants using microorganisms instead of chemical and physical treatment which may produce toxic substances (Ayangbenro \& Babalola, 2017). Bacteriophages and dried banana leaves could be a basis for bioadsorption. Bioadsorption is biological treatment, eco-friendly and economical process for water pollution treatment using less expensive techniques (Boopathy, 2000). Consequently, the aim of this study was improving physicochemical quality of wastewater using banana leaves and specific phages as well as reducing $E$. coli, $P$. aeruginosa and $S$. Typhi.

\section{Materials and Methods}

\section{Study area and sampling collection}

Three major wastewater plants, New Cairo, Gabal El-Asfar and Helwan in Egypt, which are the branches of the Nile River that received sewage, agricultural and industrial wastes, were used for collecting samples. The collection and preparation of samples were performed based on Standard Methods for Examination of Water and Wastewater (APHA, 2012). The forty samples (50L) of wastewater were collected from three plants during summer (20 July 2017 from
12.00 p.m. to 3.00 p.m., air temperature was $31^{\circ} \mathrm{C}$ ).

\section{Assessments of physicochemical parameters}

The wastewater samples were analyzed physically and chemically according to Standard Methods for Examination of Water and Wastewater (APHA, 2012). Physical and chemical parameters such as electric conductivity (EC), dissolved oxygen (DO) and total dissolved solids (TDS) were determined in-situ using multi-probe technique (Hydralab-Surveyor) and rechecked in laboratory. Ammonia $\left(\mathrm{NH}_{3}\right)$ was determined by ammonia selective electrode(ORION model 940). Biochemical oxygen demand (BOD) was determined by ORION BOD fast respiratory system (model 890) while carbonates $\mathrm{CO}_{3}^{2-}$ and bicarbonates $\mathrm{HCO}_{3}^{-}$were detected by Ion chromatography (IC-METROHM). The temperature of wastewater samples was measured by a calibrated thermometer. Evaluation of $\mathrm{pH}$ was performed using bench-top $\mathrm{pH} / \mathrm{ISE}$ meter, ORION model 710A with PerpHect $\mathrm{Ag} / \mathrm{AgCl}$ low maintenance Gel triode $\mathrm{pH}$ electrode and model 9207BN with accuracy of about \pm 0.02 .

\section{Bacteriological analysis}

Water samples were shaken up vigorously and serial dilutions were prepared in saline solution $(8.0 \mathrm{gm} \mathrm{NaCl})$. The total number of bacteria and the microbial counts were detected using Standard plate count (SPC) according to APHA (2005). Plate count agar used for counting, was obtained in a dehydrated form (Difco, USA). Two sets of duplicate plates were used for each sample dilution. One set was incubated at $37^{\circ} \mathrm{C}$ for 24-48hrs and the other set for 3-5 days at $22^{\circ} \mathrm{C}$ using cooling incubator (VWR). Viable organisms developed in the form of colonies were counted. The original numbers of organisms $(\mathrm{cfu} / \mathrm{ml})$ in water were calculated considering the dilution factor and the final estimate was taken as the average of figures obtained from the countable plates. The membrane filter technique was applied using a filtration system completed with stainless steel autoclavable manifold and oilfree "MILLIPORE" vacuum/pressure pump for determination of total and fecal coliforms, fecal streptococci, $P$. aeruginosa, $S$. Typhi and other gram-negative bacteria. Selected sample volume (depending on type of sample) was filtered on sterile and surface gridded "SARTORIOUS" membrane of pore size $0.45 \mathrm{~mm}$ and diameter $47 \mathrm{~mm}$ placed aseptically over the porous plate of the filtration unit receptacle. 


\section{Isolation of bacterial isolates}

Being the most prevailing pathogens in wastewater; Escherichia coli, Salmonella Typhi and Pseudomonas aeruginosa were isolated in studied areas. Briefly, wastewater samples were diluted and inoculated on standard plate count agar and incubated at $35^{\circ} \mathrm{C}$ for 24 to $48 \mathrm{hrs}$. After incubation, the developed colonies were isolated using selective medium (m-TEC agar medium for E. coli, Bismuth sulfite agar for Salmonella spp. and M-PA-C agar medium for Pseudomonas aeruginosa). Each of the isolates was observed for the colony characters.

\section{Biochemical identification of bacterial isolates:}

Typical colonies were sub-cultured three successive times for purification and confirmation on Eosin Methylene Blue agar plates for $E$. coli, Salmonella Shigella agar for Salmonella spp. and Cetrimide agar for Pseudomonas aeruginosa. Bacterial isolates were identified by colonial morphology, gram's staining and other conventional biochemical tests (Bergey's manual 2009).

\section{Molecular identification of bacterial isolates:}

Bacterial genomic DNA was isolated using Applied Biosystems PrepMan ${ }^{\circledR} \quad$ Ultra sample Preparation Reagent (PN 4322541) (QIAamp, Qiagen ${ }^{\circledR}$, Hilden). Two primer sets, F: 5' GGGGGATCTTCGGACCTCA -3' and R: 5> TCCTTAGAGTGCCCACCCG -3 ${ }^{\text {‘ were }}$ usedaccording to Tripathi et al. (2013).

PCR amplifies the first 500 base pairs of the 16s ribosomal DNA gene in the GeneAmp®PCR System 9700. The products were then loaded in a genetic analyzer to determine the sequence. MicroSEQ ${ }^{\circledR} \quad$ ID Analysis Software enables to analyze sequences obtained with any of the MicroSEQ ${ }^{\circledR}$ Microbial identification Kits including the MicroSEQ ${ }^{\circledR} 500$ 16s rDNA Bacterial Identification Kits. The software assembles the $16 \mathrm{~s}$ rDNA sequence for the unknown then compares the sequence with 16s rDNA sequence in the MicroSEQ ${ }^{\circledR}$ ID16s rDNA 500 Library (version I.0 and 2.0). Based on the comparison, the software provides an ID for the unknown bacterial species.

\section{Phylogenetic tree and similarity index}

The relation between isolated bacteria and other isolates were determined using the CLC software version 7.6 (Qiagen, Aarhus, Denmark).

\section{Isolation and purification of bacteriophages \\ Preparation of the phage lysates}

Different waste water samples were used for isolation of phages specific for E.coli, $P$. aeruginosa and $S$. Typhi through the liquid enrichment technique (Van Twest \& Kropinski, 2009). Each sample (About $10 \mathrm{ml}$ ) from water samples was mixed with $50 \mathrm{ml}$ of liquid culture of $E$. coli, $P$. aeruginosa and $S$. Typhi isolates with traces of $\mathrm{CaCO}_{3}$ were added to the mixture. Then, the samples were incubated at $30^{\circ} \mathrm{C}$ for $72 \mathrm{hrs}$. with shaking. After that, centrifugation at $6000 \mathrm{rpm}$ for $15 \mathrm{~min}$ was performed and chloroform was added by a ratio of 1:10 with vigorous shaking.

\section{Qualitative and quantitative assaying of phages}

Phages specific for E. coli, P. aeruginosa and $S$. Typhi were assayed qualitatively using spot test and quantitatively by over layer (plaque assay) technique (Kropinski et al., 2009). Single phage plaques specific for isolated bacterial species were selected, characterized and picked up, then transferred to $10 \mathrm{ml}$ of broth culture $\left(10^{8} \mathrm{CFU} /\right.$ $\mathrm{ml}$ ), incubated at $30^{\circ} \mathrm{C}$ for $48-72 \mathrm{hrs}$. with shaking at $150 \mathrm{rpm}$. The step was repeated three times to enhance purity of phage plaques.

\section{Purification of phages}

Dextran sulfate-polyethylene glycol was used for phage purification and concentrated using two phase liquid system (Othman et al., 2008). The mixture centrifuged at $2000 \mathrm{rpm}$ for $10 \mathrm{~min}$. Then, the supernatant was collected and centrifuged at $16000 \mathrm{rpm}$ for $2 \mathrm{hrs}$ at $4^{\circ} \mathrm{C}$. The phage pellets were resuspended in $1 \mathrm{ml}$ of saline solution and assayed.

\section{Electron microscopy examination}

The isolated phages were examined using transmission electron microscopy (TEM). The phage sample was prepared as described before (Ackermann, 2012) where drop of phage lysate $\left(10^{8} \mathrm{pfu} / \mathrm{ml}\right)$ was laid on 200 mesh carbon coated cupper grid and left them for absorption for 20 min. The excess lysate was wiped using filter paper, before the grids were negatively stained with $2 \%$ uranyl acetate $(\mathrm{pH} 4.5)$ for $90 \mathrm{sec}$ and allowed to dry, then examined by transmission electron microscopy (JEOL-JSM-5500LV; electron microscope unit, Regional Center for Mycology and Biotechnology, Al-Azhar Univ., Cairo) using high vacuum mode at an acceleration voltage of $80 \mathrm{kV}$. 
Application of dried banana leaves and phages for wastewater treatment leaves

Preparation of fine dried powder of banana

The banana leaves were collected and washed three times by sterilized water to discard any derbies. They were air dried, then grounded using blender with high speed. They were sifted using sieve, its pores with diameter at range 200 to $300 \mu \mathrm{m}$, to obtain fine powder of banana leaves.

\section{Preparation of phage cocktail}

The phage cocktail was prepared by mixing equal volumes of isolated phages $(10 \mathrm{ml}$ of each phage) specific to bacterial host (E. coli, $P$. aeruginosa and $S$. Typhi) at concentration $10^{8}$ $\mathrm{PFU} / \mathrm{ml}$ as determined by plaque assay.

Bioadsorption and bioeradication of water pollutants

Each of three wastewater samples were divided into four parts (1L for each part). First liter was untreated used as control. Second liter was treated with $(50 \mathrm{~g} / \mathrm{L})$ fine powder of banana leaves. Third liter was mixed with $10 \mathrm{ml}\left(10^{8} \mathrm{PFU} /\right.$ $\mathrm{ml})$ phage cocktail and the last one was treated with a mixture of $(50 \mathrm{~g} / \mathrm{L})$ fine powder of banana leaves and $10 \mathrm{ml}\left(10^{8} \mathrm{PFU} / \mathrm{ml}\right)$ phage cocktail. The physicochemical and bacteriological parameters were measured before and after treatment.
Statistical analysis

The data was interpreted through correlation coefficient matrixes between all pairs of bacteriological and physicochemical parameters. MINITAB statistical software program was used for calculating percentages, mean values and log transformed data. The standard deviations were determined for duplicate independent trials. The data and the differences from control (without treatment) were considered significant at $\mathrm{P}<0.05$.

\section{Results}

Physicochemical characteristics of wastewater samples

The Physicochemical values of three wastewater sites, New Cairo, Gabal El-Asfar and Helwan, indicated higher values than permissible limits as shown in Table 1.

The results in Table 1 showed detectable variations in microbial counts among the three studied sites. It is worth mentioning that, all monitoring points in stations exceeded the international standard limits (should not be more than $5 \times 10^{3} \mathrm{CFU} / 100 \mathrm{ml}^{-1}$ ).

The high level of fecal coliform (FC) Fecal streptococci (FS) was detected in all water samples.

TABLE 1. Physico-chemical and bacteriological parameters in different wastewater plants .

\begin{tabular}{|c|c|c|c|}
\hline Parameters & New Cairo & Gabal El-Asfar & Helwan \\
\hline \multicolumn{4}{|c|}{ Physicochemical parameters } \\
\hline TDS (mg/L) & 610 & 801 & 573 \\
\hline $\mathrm{EC}(\mathrm{dS} / \mathrm{m})$ & 0.975 & 0.600 & 0.491 \\
\hline NH3 (mg/L) & 23.18 & 17.92 & 25.00 \\
\hline $\mathrm{DO}(\mathrm{mg} / \mathrm{L})$ & 0.16 & 0.40 & 0.28 \\
\hline BOD (mg/L) & 125 & 119 & 170 \\
\hline \multicolumn{4}{|c|}{ Bacteriological parameters } \\
\hline $\begin{array}{l}\mathrm{SPC}(\mathrm{Log} / \mathrm{ml}) \\
22^{\circ} \mathrm{C} / 48 \mathrm{hrs}\end{array}$ & 8.28 & 7.02 & 8.38 \\
\hline $\begin{array}{l}\mathrm{SPC}(\mathrm{Log} / \mathrm{ml}) \\
35^{\circ} \mathrm{C} / 24 \mathrm{hrs}\end{array}$ & 8.27 & 6.92 & 8.04 \\
\hline $\mathrm{TC}(\log / 100 \mathrm{ml})$ & 6.24 & 5.90 & 6.91 \\
\hline FC ( $\log / 100 \mathrm{ml})$ & 5.94 & 5.48 & 5.51 \\
\hline FS $(\log / 100 \mathrm{ml})$ & 4.34 & 4.10 & 4.39 \\
\hline P. aeruginosa $(\mathrm{Log} / 100 \mathrm{ml})$ & 2.95 & 3 & 2.81 \\
\hline
\end{tabular}


In order to interpret results obtained from large quantity of data and to gain knowledge about the relationship between different physicochemical and bacteriological parameters, the correlation coefficient matrix was calculated as shown in Table 2. Significant correlation $(\mathrm{r}=+0.98)$ between BOD \& TC \& FC \& FS showed statistically high positive, while showed high negative correlation between DO and both of TC, FC and FS. This is indication for water pollution with bacterial contamination.

\section{Bacterial isolates}

Eighty bacterial isolates out of 210 bacterial colonies were isolated from different waste water samples of studied sites. They identified based on the identical cultural characters, morphology of bacterial colonies and bacterial cells morphology. Furthermore, the identification of bacterial isolates was confirmed according to Bergey's Manual of Systematic Bacteriology and 16s DNA gene. As recorded in Table 3, three bacterial isolates, the most abundant pathogens in the studied areas, were counted as E. coli (61.4\%), S. Typhi (35.2\%) which are related to Enterobactericeae and P. aeruginosa (3.3\%) relevant to Pseudomonadaceae.
Molecular identification of bacterial isolates

Isolated bacteria were confirmed by $16 \mathrm{~s}$ rDNA gene using PCR. PCR amplifies expected size 500 bp of the 16s rDNA gene in the GeneAmp ${ }^{\circledR P C R}$ System 9700 . The software assembles the $16 \mathrm{~s}$ rDNA sequence for the unknown then compares the sequence with 16s rDNA sequence in the MicroSEQ ${ }^{\circledR}$ ID16s rDNA 500 Library (version I.0 and 2.0).

\section{Sequence analyses}

Multiple sequence alignments were subjected to variability analysis among isolated bacteria using DNAMAN and MEGA.4 programmers (Wisconsin, Madison, USA) and aligned with bacterial species recorded on the Genbank. Phylogenetic tree representing the relationship between the bacterial species published on the Genbank and isolated bacteria based on DNA sequence homology $(79,76$ and $67 \%$ for $E$. coli, S. Typhi and P. aeruginosa respectively), distance and homology matrix representing the relationship between bacterial species published on the Genbank and Egyptian isolates. The phylogenetic tree was performed and shows four clusters (Fig. 1 A, B and C).

TABLE 2. Correlation coefficient matrix between physicochemical and bacteriological parameters.

\begin{tabular}{|c|c|c|c|c|c|}
\hline Variable & DO & OD & TC & FC & FS \\
\hline DO & 1.00 & & & & \\
\hline BOD & 0.14 & 1.00 & & & \\
\hline $\mathrm{TC}$ & -0.72 & 0.98 & 1.00 & & \\
\hline FC & -0.89 & 0.81 & -0.13 & 1.00 & \\
\hline FS & -0.77 & 0.73 & 0.85 & 0.41 & 1.00 \\
\hline
\end{tabular}

- (1): Perfect positive correlation, (0.8): High positive correlation, (0.3): Low positive correlation, (0): No correlation, (-1): Perfect negative correlation, $(-0.8)$ : High negative correlation, $(-0.3)$ : Low negative correlation.

- Do: Dissolved oxygen, BOD: Biological oxygen demand, SPC: Standard plate count, TC: Total coliform. FC: Fecal coliform, FS: Fecal Streptococci.

TABLE 3. Total count and frequency of pathogenic bacteria species isolated from wastewater.

\begin{tabular}{lccccc}
\hline Species & New Cairo & Gabal El-Asfar & Helwan & Total & Frequency \% \\
\hline Escherichia coli & 45 & 47 & 37 & 129 & $61.4 \%$ \\
Pseudomonas aeruginosa & 23 & 33 & 18 & 74 & $35.2 \%$ \\
Salmonella Typhi & 3 & 2 & 2 & 7 & $3.3 \%$ \\
Total & 71 & 82 & 57 & 210 & $100 \%$ \\
\hline
\end{tabular}



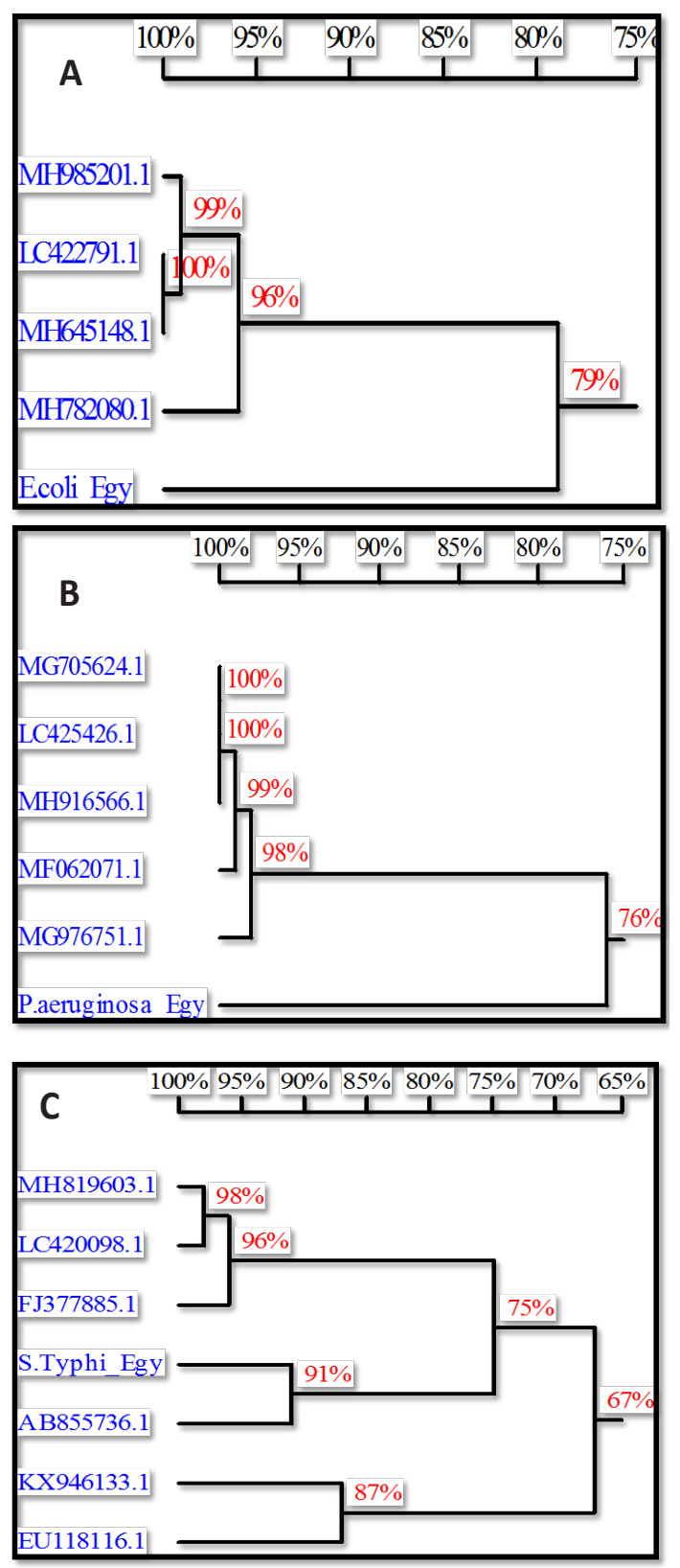

Fig. 1. Phylogenetic tree representing the relationship between the bacterial species (A) $E$. coli, (B) $P$. aeruginosa and (C) $S$. Typhi recorded on the Genbank and Egyptian isolates based on DNA sequence homology.

Identification of lytic phages specific to E. coli, $P$. aeruginosa and $S$. Typhi

Eight phages specific to three bacterial isolates were isolated of each $E$. coli isolates (A2 \& B2), S. Typhi isolates (A3 \& 102) and $P$. aeruginosa isolate (A1). The lytic phages were selected based on differences of plaque morphology (Fig. 2, Table 4). The activity and titer of specific bacteriophages were determined by spot test and plaque assay test. As shown in Table 4, using single plaque isolation technique resulted in three single phage isolates for E.coli, $P$. aeruginosa and $S$. Typhi. All isolated phages formed circular plaques whose diameters ranged between $1 \mathrm{~mm}$ to $5 \mathrm{~mm}$. These phages specific to $E$. coli were named as $\mathrm{C} 1, \mathrm{C} 2$ and $\mathrm{C} 3, P$. aeruginosa phages were known Ps1, Ps2 and Ps3 and $S$. Typhi phages were defined as S1 and S2. Dextran sulfate-polyethylene glycol two phase systems were used to obtain a purified and concentrated phage preparation.

\section{Phage morphology}

Eight selected phages for bacterial species isolated from sewage were examined by TEM. The head of all examined phages was icosahedral and the phages were with or without. The examined phages showed different morphotypes (Fig. 3). E. coli phages (Eco-1 and Eco-2), $P$. aeroginosa phage (Ps-1), $S$. Typhi phage (Sal1) are related to Siphoviridae. Whereas, E. coli phage (Eco-3) and P. aeruginosa phage (Ps-2) are related to Myoviridae that characterized by a short tail with contractile sheath. On the other hand, $P$. aeruginosa phage (Ps-3) and $S$. Typhi phage (Sal-2) do not have tail and thus they were related to the Podoviridae. The head diameter and tail length were determined as shown in Table 5.

The efficacy of banana leaves and phage cocktail on physicochemical parameters of wastewater

The changes in physical and chemical parameters were observed after wastewater treatment using fine powdered banana leaves and phage cocktail. The results showed variations in the effect of banana leaves and phage cocktail on the presence of wastewater pollutants. The treatment resulted in reducing the concentrations of BOD, COD and turbidity. In addition, there was an increase in the concentration of TDS and DO. On the other hand, there was a slight effect on temperature and $\mathrm{pH}$. The significant effectiveness was observed in the treatment of sewage water using mixture of banana leaves and phage cocktail rather than using plant only $(\mathrm{P}<0.05)$ (Table 6). The standard deviations were determined for duplicate independent trials. The data and the differences from control (without treatment) were considered significant at $\mathrm{P}<0.05$. 

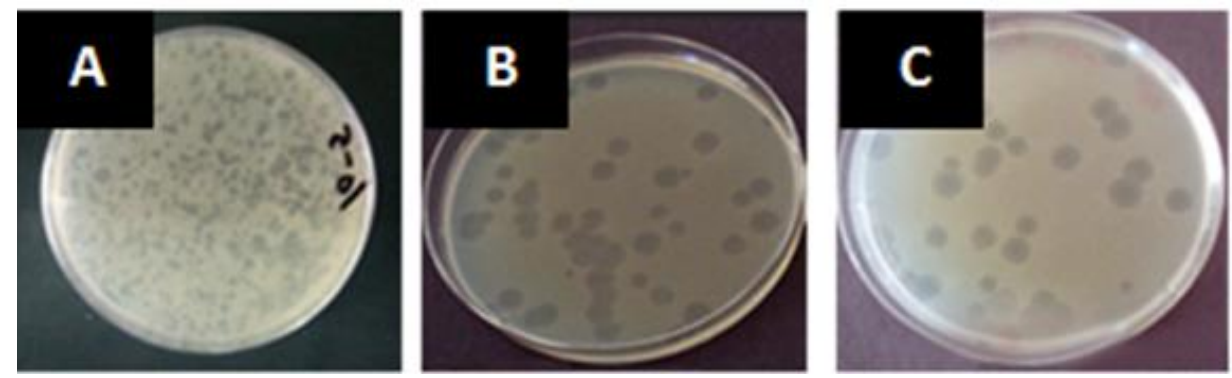

Fig. 2. Plaque assay technique illustrates the presence of different morphological plaques; A: Phages specific for $E$. coli strain A2, B: Phages specific for $P$. aeruginosa strain A1, C: Phages specific for $S$. Typhi strain.

TABLE 4. Plaques morphology and titers of phages specific to E. coli, P. aeruginosa and $S$. Typhi.

\begin{tabular}{|c|c|c|c|c|c|}
\hline $\begin{array}{l}\text { Phage } \\
\text { isolates }\end{array}$ & Bacterial host & Diameter & $\begin{array}{c}\text { Plaque } \\
\text { morphology }\end{array}$ & $\begin{array}{l}\text { Plaque assay test } \\
\quad\left(\text { PFU ml }{ }^{-1}\right)\end{array}$ & Site \\
\hline Eco- $1^{*}$ & E. coli strain A2 & $3 \mathrm{~mm}$ & $\begin{array}{l}\text { Circular } \\
\text { Turbid } \\
\text { Regular }\end{array}$ & $50 \times 10^{2}$ & WWTPs \\
\hline Eco-2 & E. coli strain A2 & $2 \mathrm{~mm}$ & $\begin{array}{l}\text { Circular } \\
\text { Clear } \\
\text { Regular }\end{array}$ & $35 \times 10^{2}$ & WWTPs \\
\hline Eco-3 & E. coli strain B2 & $1 \mathrm{~mm}$ & $\begin{array}{l}\text { Circular } \\
\text { Clear } \\
\text { Regular }\end{array}$ & $27 \times 10^{2}$ & WWTPs \\
\hline **Ps-1 & P. aeruginosa strain A1 & $4 \mathrm{~mm}$ & $\begin{array}{l}\text { Circular } \\
\text { Clear } \\
\text { Regular }\end{array}$ & $16 \times 10^{2}$ & WWTPs \\
\hline Ps-2 & P. aeruginosa strain $\mathrm{A} 1$ & $1 \mathrm{~mm}$ & $\begin{array}{l}\text { Circular } \\
\text { Turbid } \\
\text { Irregular }\end{array}$ & $80 \times 10^{2}$ & WWTPs \\
\hline Ps-3 & P. aeruginosa strain A1 & $5 \mathrm{~mm}$ & $\begin{array}{l}\text { Circular } \\
\text { Turbid } \\
\text { Regular }\end{array}$ & $39 \times 10^{2}$ & WWTPs \\
\hline ***Sal-1 & S. Typhi strain A3 & $2 \mathrm{~mm}$ & $\begin{array}{l}\text { Circular } \\
\text { Clear } \\
\text { Regular }\end{array}$ & $101 \times 10^{2}$ & WWTPs \\
\hline Sal-2 & S. Typhi strain 102 & $2 \mathrm{~mm}$ & $\begin{array}{l}\text { Circular } \\
\text { Clear } \\
\text { Irregular }\end{array}$ & $66 \times 10^{2}$ & WWTPs \\
\hline
\end{tabular}

- The letter Eco refers to coliform bacteria $E$. coli and numbers 1 to 3 are the isolated phage numbers.

- The letter Ps refers to coliform bacteria $P$. aeruginosa and numbers 1 to 3 are the isolated phage numbers.

- The letter Sal refers to coliform bacteria $S$. Typhi and numbers 1 to 2 are the isolated phage numbers.

Bio-control of pathogenic bacteria using mixture of phages and banana plant:

The Bio-adsorption efficacy of banana leaves and the lytic activity of phages cocktail to bio-control pathogenic bacteria were applied in sewage water. A mixture of banana leaves fine powder and phage cocktail showed a significant reduction of pathogenic bacteria $(\mathrm{P}<0.05)$. About $2 \log$ reduction of bacterial growth was observed using banana leaves as well as phages cocktail, using individual treatments. Whereas, up to 4 $\log$ reduction was showed by using a mixture of banana leaves fine powder and phage cocktail (Fig. 4). The standard deviations were determined for duplicate independent trials. The data and the differences from control (without treatment) were considered significant at $\mathrm{P}<0.05$. 

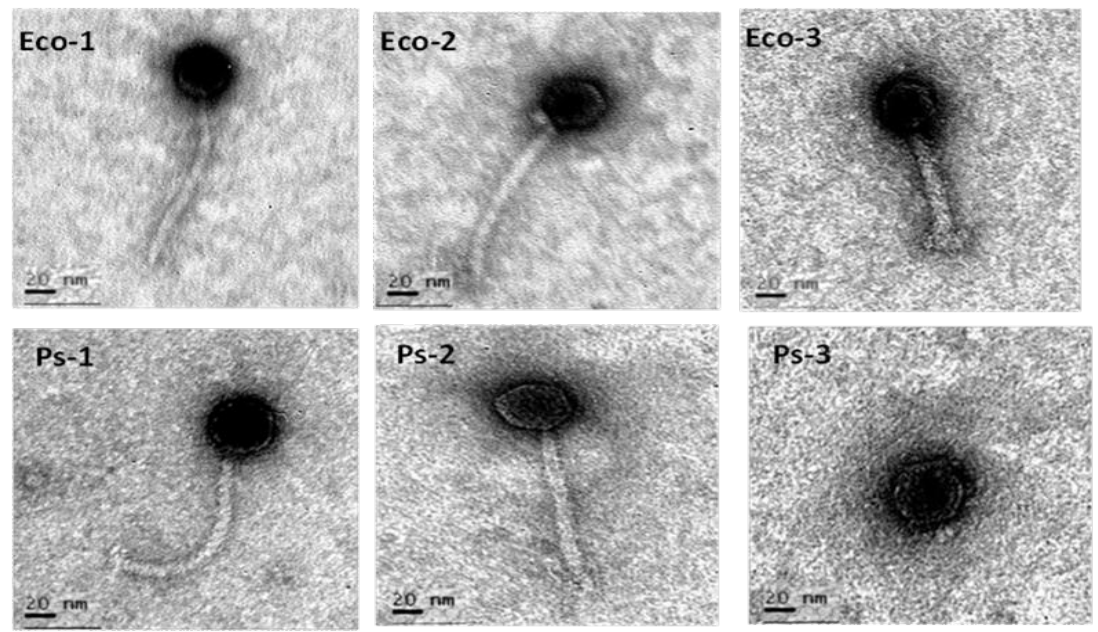

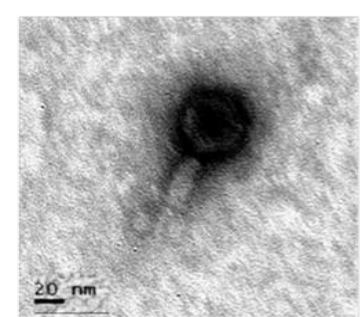

Image showed the contracted tail of phage
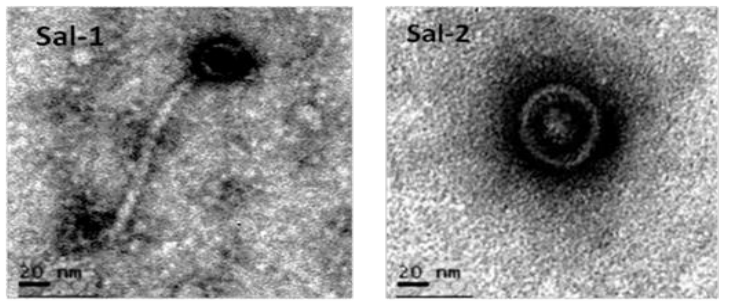

Fig . 3. Electro-micrograph represents the morphology of eight different phages specific to $E$. coli, P.aeruginosa and $S$. Typhi isolates using TEM. . *Eco refers to coliform bacteria $E$. coli and numbers 1 to 3 are the isolated phage numbers. *Ps refers to coliform bacteria $P$. aeruginosa and numbers 1 to 3 are the isolated phage numbers. *Sal refers to coliform bacteria $S$. Typhi and numbers 1 to 2 are the isolated phage numbers.

TABLE 5. Morphological properties of isolated phages.

\begin{tabular}{lccc}
\hline Phage & Size & Tail length $(\mathbf{n m})$ & Family \\
\hline Eco-1 & 80.0 & 171.08 & Siphoviridae \\
Eco-2 & 94.00 & 167.08 & Siphoviridae \\
Eco-3 & 103.00 & 101.01 & Myoviridae \\
Ps-1 & 90.00 & 165.33 & Siphoviridae \\
Ps-2 & 91.00 & 135.00 & Myoviridae \\
Ps-3 & 85.00 & & Podoviridae \\
Sal-1 & 64.00 & 203.30 & Siphoviridae \\
Sal-2 & 70.00 & & Podoviridae \\
\hline
\end{tabular}

- Eco refers to coliform bacteria $E$. coli and numbers 1 to 3 are the isolated phage numbers.

- Ps refers to coliform bacteria $P$. aeruginosa and numbers 1 to 3 are the isolated phage numbers.

- Sal refers to coliform bacteria $S$. Typhi and numbers 1 to 2 are the isolated phage numbers. 
TABLE 6. Physico-chemical properties of wastewater after treatment using banana leaves and phage cocktail.

\begin{tabular}{lcccc}
\hline Parameter & Unit & $\begin{array}{c}\text { Before treatment } \\
\text { (control) } \pm \text { SD }\end{array}$ & $\begin{array}{c}\text { Banana leaves } \\
\text { treatment } \pm \text { SD }\end{array}$ & $\begin{array}{c}\text { Banana leaves \& phage } \\
\text { treatment } \pm \text { SD }\end{array}$ \\
\hline Temperature & ${ }^{\circ} \mathrm{C}$ & $28 \pm 0.14$ & $31 \pm 0.18$ & $31.8 \pm 0.28$ \\
$\mathrm{pH}$ & & $7.35 \pm 0.49$ & $7.72 \pm 0.57$ & $7.50 \pm 0.47$ \\
$\mathrm{EC}$ & $\mathrm{mS} / \mathrm{cm}$ & $0.975 \pm 0.33$ & $1.688 \pm 0.23$ & $1.02 \pm 0.29$ \\
$\mathrm{NH} 3$ & $\mathrm{mg} / \mathrm{L}$ & $23.18 \pm 0.51$ & $16.02 \pm 0.12^{*}$ & $9.01 \pm 0.57^{*}$ \\
Total Alkalinity & $\mathrm{mg} / \mathrm{L}$ & 302.5 & $473.4^{*}$ & 298.2 \\
$\mathrm{CO} 3$ & $\mathrm{mg} / \mathrm{L}$ & $\mathrm{ND}$ & $\mathrm{ND}$ & $\mathrm{ND}$ \\
$\mathrm{HCO} 3$ & $\mathrm{mg} / \mathrm{L}$ & $302.5 \pm 0.28$ & $473.4 \pm 0.05^{*}$ & $298.2 \pm 0.19^{*}$ \\
BOD & $\mathrm{mg} / \mathrm{L}$ & $125 \pm 0.23$ & $98 \pm 0.39^{*}$ & $25 \pm 0.28^{*}$ \\
COD & $\mathrm{mg} / \mathrm{L}$ & $233 \pm 0.14$ & $150 \pm 0.30^{*}$ & $71 \pm 0.29^{*}$ \\
DO & $\mathrm{mg} / \mathrm{L}$ & $0.16 \pm 0.16$ & $2.01 \pm 0.29^{*}$ & $6.02 \pm 0.31^{*}$ \\
Turbidity & $\mathrm{mg} / \mathrm{L}$ & $260 \pm 0.47$ & $170 \pm 0.61^{*}$ & $149 \pm 0.32^{*}$ \\
TDS & $\mathrm{mg} / \mathrm{L}$ & $610 \pm 0.22$ & $1080 \pm 0.55^{*}$ & $744 \pm 0.35$ \\
TSS & $\mathrm{mg} / \mathrm{L}$ & $400 \pm 0.33$ & $460 \pm 0.35$ & $391 \pm 0.57$ \\
\hline
\end{tabular}

- The data represent the mean \pm standard deviation (SD),

- *: A significantly different from the control (before treatment) $(\mathrm{P}<0.05)$.

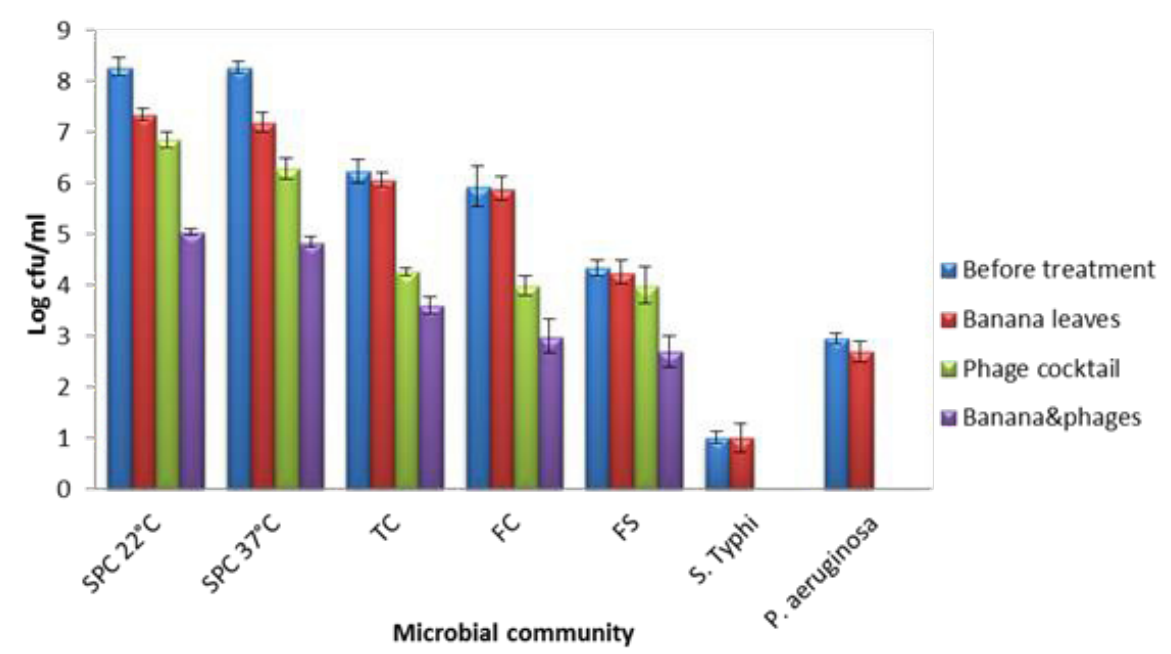

Fig. 4. Histogram showing the bio-control of bacterial pathogens in sewage water using a mixture of banana leaves powder and phage cocktail [SPC: Standard plate count, TC: Total coliform, FC: Fecal coliform, FS: Fecal Streptococci. Statistically significant treatments compared to the control (initial conc.) were indicated by “*” where $\mathbf{P}<$ 0.05. The population count below detection limit (less than $1 \log \mathrm{CFU} / \mathrm{ml}$ ) is indicated by "***"].

\section{Discussion}

Wastewater treatment is a necessity for human health and the environment. The current study intended to improve wastewater treatment using biological approach. The water quality assessments of three studied areas were carried out through in accordance with previous studies (Andhra, 2018). The Physico-Chemical values of three wastewater sites indicated higher values than permissible limits (APHA, 2012). The results showed higher values in turbidity, $\mathrm{NH}_{3}$, TDS, $\mathrm{EC}, \mathrm{BOD}$ and total alkalinity concentrations in addition to depletion in DO. DO is the availability of oxygen for the aerobic metabolism and organic decomposition (Subashree et al., 2017). DO is often acts as water quality indicator. Inadequate DO may contribute to anaerobic condition that leads to water deterioration and unfavorable odors that belongs to the production of $\mathrm{H}_{2} \mathrm{~S}, \mathrm{NH}_{3}$ and $\mathrm{CH}_{4}$ gases (El-Sherbini et al., 1997) and accumulation of organic matter and nutrients load (El-Gamal $\&$ Shafik, 1985). BOD is oxygen consumed for microbial metabolic requirements during the breakdown of organic matter. It reflects the level of organic materials causing water pollution as 
reported by Chapman (1992). Total Coliforms (TC) are used as good indicators for quality of water, It is worth mentioning that, all monitoring points in stations exceeded the international standard limits recommended by (Tebbutt, 1998; AboElEnien et al., 2017). A maximum count of total coliforms is about 1000 cfu100 $\mathrm{ml}^{-1}$, especially in water surface which are used as water supply for drinking (Cabelli, 1978; El-Rawady \& Cedare, 2014). TC are used as a good indicator for quality of water, fecal coliforms (FC) is the serious form of pollution for many rivers everywhere. Feces, from human source containing enteric pathogens, commonly causes the higher risk to public health. According to several reports, the ratio FC/FS was used to determine source of fecal pollution is from human or animal wastes. Furthermore, the counts of TC, FC and FS exceeded the permissible limits. Fecal contamination is a serious form of pollution for many rivers everywhere. Feces from human source containing enteric pathogens commonly cause the higher risk to public health (Bhadra et al., 2003; David et al., 2017). It seems that all wastewater treatment stations did not comply with the international standard limits (Tebbutt, 1998; El-Gamal \& Housian, 2016). Restricted limits for surface water intended for using as supply of drinking water indicated the unsafe usage of water based on bacteriological point of view (Cabelli, 1978; Gabr, 2018).

Three isolated bacteria, E. coli, $P$. aeruginosa and $S$. Typhi, were detected, counted and identified. Generally, the identified bacteria in this study were investigated as pathogenic bacteria with human health concern (Sneath, 1986; Cheesbrough, 2006; WHO, 2011; Azzam et al., 2017). The presence of $E$. coli and E. faecalis in wastewater sites acts as an indicator for the contamination with sewage and fecal coliform (Edberg et al., 2000).

The identification of bacterial isolates was carried out according to Bergey's Manual of Systematic Bacteriology. Morphological and biochemical characteristics of identified isolates were determined as shown in Brenner et al. (2005) and De Vos et al. (2009). The identified bacterial isolates was confirmed by $16 \mathrm{~s}$ rDNA gene using PCR. The resulted sequences were compared with bacterial species recorded on the Genbank using DNAMAN program and identified as E. coli, $P$. aeuroginosa and S. Typhi (Lin \& Tong, 2013; Momen, 2016).
Three phages specific to $E$. coli, three for $P$. aeruginosa and two phages related to $S$. Typhi were isolated and characterized by transmission electron microscope. All isolated phages specific for E. coli, P. aeruginosa and $S$. Typhi produce a circular, clear or turbid plaque ranged from $1 \mathrm{~mm}$ and $5 \mathrm{~mm}$ in diameter. Zahra et al. (2014) obtained also circular plaques varied from 1 to $4 \mathrm{~mm}$ in diameter for five coliphage isolated from sewage water. Zahra et al. (2014) and $\mathrm{Lu}$ et al. (2018) isolated phages specific for $P$. aeroginosa and $S$. Typhi from sewage water.

The banana leaves were applied as fine powder for bioremediation of pollutants in waste water. Using banana fine powder leads to increasing the specific surface that increasing bio-adsorbent of large amounts of pollutants, metals and pathogens, from wastewater. The obtained results showed that gradual improvement recognized at the treatment of waste water using fine powder of banana leaves (Daud et al., 2017). In addition to that, they are attributed most probably to purification and disinfection concepts as well as reduction of bacterial pathogens with percentage ranged between $92-96 \%$ \& $75-100 \%$ for physicochemical and microbiological values, respectively. The results showed the efficacy of using banana leaves powder in the reduction of BOD, $\mathrm{NH}_{3}$ and TDS, COD. Furthermore, it has a significant effect on the availability of metals as reported by Subramanian et al. (2007). Thus, banana powder could be used for the bio-adsorption of soluble form of heavy metals in wastewaters which have raised increasing concern in several countries (Anupriya et al., 2018). Another study showed the effectiveness of $\mathrm{Cu}$ and $\mathrm{Pb}$ adsorption onto banana peels powder (Naikwade et al., 2014; Giorgio et al., 2017).

However, in this study, applying the mixture of banana leaf powder with phage cocktail specific to $E$. coli, $P$. aeruginosa and $S$. Typhi has an effect on physicochemical parameters and a significant reduction on bacterial pathogens in wastewater.

A previous study proved that the effect of phages belongs to adsorption sites on the surface of bacteriophage T4. These sites are found to be negatively charged through the zeta potential analysis and thus, demonstrating the capabilities of these viruses at adsorbing positively charged metal cations, Studies have also shown that microbes can be responsible for both the mobilization and 
immobilization of heavy metals in the subsurface, which influences the storage and release of these metals in the environment that these microbes are present in (Oyewo et al., 2018; Mohamed et al., 2020). This demonstrates the potential of viruses which are much more abundant than bacteria, to be a potential player in contaminant mobility in subsurface environments. Bioaccumulation of these heavy metals and also biosorption by microbial biomass have been determined to influence the mobility of such pollutants (Ahmad et al., 2005; Dey et al., 2018). Biosorption of heavy metals and radionuclides have long been associated with microbially mediated bioremediation techniques (Schwizer et al., 2018; El-Sayed, 2019). This agrees with the findings of most studies out there which have proven that most divalent metal cations are able to help increase or enhance the infectivity of bacteriophages (Adams, 1949b). When the infectivity of viruses increases, this means that there will be a rise in the occurrences of bacterial lysis in the ecosystem, which could bring about the release of organic carbon and nutrients into the environment.

The abundance of microbial communities may also affect viral lysis when species of microbes are targeted by bacteriophages in the environment.

Furthermore, the bacteriophage showed a delaying the growth of bacterial pathogens in wastewater, that belongs the high lytic activity on bacterial host. This study showed a significant reduction of bacterial growth with using phage cocktail another recent study showed using phage cocktail was more efficient with commercial applications in bacteriophage therapy against Salmonella (Bardina et al., 2016). As a result of all this, using phage cocktail has a great effect in bio-desorption, bioremediation of pollutants and recycling of wastewater (Gaikwad et al., 2014; Zhao et al., 2009).

\section{Conclusion and Recommendations}

The safety of wastewater and the assessment of the water quality were conducted through the evaluation of physicochemical properties and the diversity of microbial community. Consequently, bacteriophages and fine powder of banana leaves were applied as bio-control and bio-adsorbent agents for enhancement the safety of wastewater and water recycling for recreational and irrigation usages. Accordingly, formulating a mixture from fine powder of banana leaves and bacteriophages could be of interest as alternative for recycling wastewater for use in agriculture, industrial and other purposes. Furthermore, more research is needed to understand the possibility of using phages and banana leaves for eradication of pollutants from wastewater on a large scale.

\section{$\underline{\text { References }}$}

Ackermann, H.W. (2012) Bacteriophage Electron Microscopy. Adv. Virus Res. 82, 1-32.

Abo-ElEnien, S.A., Khalil, M.H., Gedamy, Y.R., Salem, H.Z. (2017) Chemical and bacteriological impacts of wastewater on the water resources at Atfih Area, Giza Governorate, Egypt. Egypt. J. Chem. 60, 10291043

Adams, M.H. (1949b) The stability of bacterial viruses in solutions of salts. J. Gen. Physiol. 32, 579-594.

Ahmad, I., Hayat, S., Pichtel, J. (2005) "Heavy Metal Contamination of Soil: Problems and Remedies". Enfield, NH: Science Publishers.

Andhra, P.I. (2018) Treatment of gray water for reusing in non-potable purpose to conserve water in India. Int. J. Applied Environ. Sci. 13(8), 703-716.

Anupriya, J., Naufal, R.P.S., Jansi, S.S, Muthu, P.K., Chella, G.C. (2018) Waste water treatment using banana stem extract from textile industries. Int. J. Appl. Environ. Sci. 13, 105-119.

APHA (American Public Health Association) (2005) "Standard Methods for the Examination of Water and Wastewater", (21 $1^{\text {st }}$ ed.), Washington, D.C.

APHA (American Public Health Association) (2012) "Standard Methods for the Examination of Water and Wastewater" $22^{\text {nd }}$ ed., Washington, D.C.

Ayangbenro, B.A., Babalola, Q.Q. (2017) A new strategy for heavy metal polluted environments: A review of microbial biosorbents. Int. J. Environ. Res. Public Health, 14, 94.

Azab, M.S. (2008) Waste-waste treatment technology and environmental management using sawdust biomixture. J. Taibah Univ. Sci. 1, 12-23.

Azzam, M.I., Ezzat, S.M., Othman, B.A., El-Dougdug, K.A. (2017) Antibiotics resistance phenomenon 
and virulence ability in bacteria from water environment. Water Sci. 31, 109-121.

Bardina, C., Colom, J., Spricigo, D.A., Otero, J., Sánchez-Osuna, M., Cortés, P., Llagostera, M. (2016) Genomics of three new bacteriophages useful in the biocontrol of Salmonella. Front. Microbiol. 7, 545.

Brenner, D.J., Krieg, N.R., Staley, J.T. (2005) "Bergeys Manual of Systematic Bacteriology". $2^{\text {nd }}$ ed. V. (2), the Proteobacteria. Springer, New York.

Bhadra, B., Mukherjee, S., Charkraborty, R., Nauda, A.K. (2003) Physico-chemical and bacteriological investigation on the River Torsa of North Bengal. Environ. Biol. 24, 125-133.

Boopathy, R. (2000) Factors limiting bioremediation technologies. Bioresour Technol. 74, 63-67.

Cabelli, V. (1978) New standards for enteric bacteria In: "Water Pollution Microbiology". Mitchell, R. (Ed.), pp. 233-271, 2. John Wiley, New York.

Chapman, D. (1992) "Water Quality Assessments", $1^{\text {st }}$ ed. Chapman and Hall, London and New York.

Chaurasia, M., Pandey, G.C. (2007) Study of physicochemical characteristic of some water ponds of Ayodhya, Faizabad. Indian J. Environ. Prot. 27, 1019-1023.

Cheesbrough, M. (2006) "District Laboratory Practice in Tropical Countries", $2^{\text {nd }}$ ed., Cambridge university press, New York.

Daud, Z., Suhani, N., Maya, R., Mohamed, S.R., Awang, H. (2017) Feasibility of banana (Musa sapientum) Trunk biofibres for treating kitchen wastewater. Nat. Environ. Pol. Technol. 16(4), 1205-1210.

David, P.A., Dhivya, B.K., Durairaj, P., Kaleeswaran, M., Abinaya, S. (2017) Treatment of gray water using constructed wetland system. Int. J. Eng. Res. Mod. Edu. 13, 116-118.

De Vos, P., George, G.M., Jones, D., Krieg, N.R., Ludwig, W., Rainey, F.A., Schleifer, K., Whitman, W.B. (2009) "Bergey's Manual of Systematic Bacteriology". $2^{\text {nd }}$ ed. Vol. 3, the Firmicutes. Springer, New York.
Dey, T.K., Hasan, M.D., Paul, S., Islam, M.B., Akanda, Y. (2018) Performance evaluation and effectiveness of different natural bio-adsorbents for wastewater treatment. Int. J. Current Eng. Technol. 8, 23475161.

Edberg, S.C., Rice, E.W., Karlin, R.J., Allen, M.J. (2000) Escherichia coli: The best biological drinking water indicator for public health protection. J. Appl. Microbiol. 88, 106-116.

El-Dougdoug, N.K., Cucic, S., Abdelhamid, A.G., Brovko, L., Kropinski, A.M., Griffiths, M.W., Anany, H. (2019) Control of Salmonella newport on cherry tomato using a cocktail of lytic bacteriophages. Int. J. Food Microbiol. 293, 60-71.

El-Gamal, T.T., Housian, M.H. (2016) Wastewater challenges and the successful implementation of constructed wetlands in Egypt. In: "Safe Use of Wastewater in Agriculture", Hir. Het. and Reza Arda (Eds.), 3.

El-Gamal, A., Shafik, Y. (1985) A study on the monitoring of pollutants discharging to the River Nile and their effect on River water quality. Water Qual. Bull. 10, 111-115.

El-Rawady, A.K., Cedare, M. (2014) 2030 strategic version for treated wastewater reuse in Egypt. Water resource management program-CEDARE.

El-Sayed, M.T. (2019) Cadmium biosorption from wastewater by Yarrowia lipolytica AUMC 9256. Egypt. J. Bot. 59, 151-169.

El-Sayed, W.S., Ouf, S.A., Mohamed, A.A.H. (2015) Deterioration to extinction of wastewater bacteria by non-thermal atmospheric pressure air plasma as assessed by $16 \mathrm{~S}$ rDNA-DGGE fingerprinting. Front. Microbiol. 6(1098), 1-13.

El-Sherbini, A.M., Bary, M.R.A., Heikal, M.T., Hamdy, A. (1997) Environmental impacts of pollution sources on Rosetta branch water quality. V. II. Water Quality and Pollution Control. CIHEAM Int. Conf. pp. 22-26.

Gabr, M.E. (2018) Wastewater reuse standards for agriculture irrigation in Egypt. $21^{\text {st }}$ International Water Technology Conference, IWTC21.Ismailia, 28-30.

Gaikwad G.L., Wate, S.R., Ramteke D.S., 
Roychoudhury K. (2014) Development of microbial consortia for the effective treatment of complex wastewater. J. Bioremed. Biodeg. 5, 227.

Giorgio, V., Luca, D.P., Nicola, V. (2017) Heavy metals adsorption by banana peels micro-powder. Equilibrium model-ing by non-linear models. Chin. J. Chem. Eng. 30565-7.

Kropinski A., Mazzacco, A., Waddell, T.E., Lingohr, E.J., Johnson, R. (2009) Enumeration of bacteriophages by double agar overlay plaque assay. Methods Mol. Biol. 501, 69-76.

Lin, Y., Tong, Z. (2013) Bacterial communities in different sections of a municipal wastewater treatment plant revealed by $16 \mathrm{~S}$ rDNA 454 Pyrosequencing. Appl. Microbiol. Biotechnol. 97, 2681-2690

Lu, X., Du, S., Horikawa, S., Chen, H., Liu, Y., Chin, B. (2018) Capture and identification of Salmonella typhymurium from large volumes of water using phage filter. Sens Agri. Food Qual Saf, 8, 12-31.

Mohamed, M.S., El-Arabi, N.I., El-Hussein, A., Abu El-Maaty, S., Abdelhadi, A.A. (2020) Reduction of chromium-VI by chromium-resistant Escherichia coli FACU: A prospective bacterium for bioremediation. Folia Microbiol.(Praha) https:// doi.org/10.1007/s12223-020-00771-y.

Momen, S.K.M. (2016) Characterization and molecular identification of unknown bacteria isolated from outlet of Arab El Madabegh sewage treatment plant in Assiut City, Egypt. J. Ecol. Hel. Environ. 1, 1-5.

Naikwade, P.V., Salavi, G., Dalavi, S., Jadhav, K. (2014) Evaluation of antibacterial properties of Musa paradisiaca L. leaves. National Conference on Conservation of Natural Resources \& Biodiversity for Sustainable.

Novo, A., André, S., Viana, P., Nunes, O., Manaia, C. (2013) Antibiotic resistance, antimicrobial residues and bacterial community composition in urban wastewater. Water Res. 47, 1875-1887.

Othman, B.A., Askora, A.A., Awny, N.M., AboSenna, A.S. (2008) Characterization of virulent bacteriophages for Streptomyces griseoflavus isolated from soil. Pak. J. Biotechnol. 5, 109-119.

Ouf, S.A., Yehia, R.S., Ouf, A.S., Abdul-Rahim, R.F.,
(2018) Bacterial contamination and health risks of drinking water from the municipal non-government managed water treatment plants. Environ. Monit. Assess. 190, 685

Oyewo, O.A., Agboola, O., Onyango, M.S., Popoola, P., Bobape, M.F. (2018) Chapter 6, current methods for the remediation of acid mine drainage including continuous removal of metals from wastewater and mine dump. In: Biog. Mine Site Rehabilitation, pp. $103-114$.

Rathore, D.S., Rai, N., Ashiya, P. (2014) Physico chemical analysis of water of Ayad river at Udaipur, Rajasthan (India). Int. J. Innov. Res. Sci. Eng. Technol. 3(4), 11660-11667.

Ravi, K.B., Lakshmi, P.M., Srinivasa, R.D., Sambasiva, R.K. (2013) Bioremediation of sewage using specific consortium of microorganisms. Int. J. Nat. Soc. Sci. 1(6), 15-26.

Schwizer, F., Okamoto, Y., Heinisch, T., Gu, Y., Pellizzoni, M.M., Lebrun, V. (2018) Artificial metalloenzymes: Reaction scope and optimization strategies. Chem. Rev. 118, 142-231.

Shannon, K.E., Lee, D.Y., Trevors, J.T., Beaudette, L.A. (2007) Application of real-time quantitative PCR for the detection of selected bacterial pathogens during municipal wastewater treatment. Sci. Total Environ. 382, 121-129.

Sneath, P.H. (1986) "Bergey"s Manual of Systematic Bacteriology", Williams and Wilkins, Baltimore, London, Los Angeles, Sydney, U.S.A. (2).

Subashree, R., Suryapraba, N., Anusha, G. (2017) Treatment of wastewater using banana and lemon peels as adsorbents. Int. J. Eng. Technol. Sci. Res. 4.

Tamil, S.A., Anjugam, E., Archana, D.R., Madhan, B., Kannappan, S. (2012) Isolation and characterization of bacteria from tannery effluent treatment plant and their tolerance to heavy metals and antibodies. Asian J. Exp. Biol. Sci. 3, 34-41.

Tebbutt, T. (1998) "Principles of Water Quality Control", $5^{\text {th }}$ ed., Hallam University.

Tripathi, P., Banerjee, G., Gupta, M., Saxena, S., Ramteke, P. (2013) Assessment of phylogenetic affiliation using 16s rRNA gene sequence analysis for P.aeruginosa in patients of lower respiratory 
tract infection. Indian J. Med. Res. 138, 557-559.

Usharani, K., Umarani, K., Ayyasamy, P., Shanthi, K. (2010) Physicochemical and bacteriological characteristics of Noyal River and ground water quality of Perur. India. J. Appl. Sci. Environ. Manage, 14, 29-35.

Van Twest, R., Kropinski, A.M. (2009) Bacteriophage enrichment from water and soil. Methods Mol. Biol. 501, 15-21.

Vasconcellos, S.P., Cereda, M.P., Cagnon, J.R., Foglio, M.A., Rodrigues, R.A., Manfio, G.P., Oliveira, V.M. (2009) In vitro degradation of linamarin by microorganism isolated from cassava wastewater treatment lagoons. Braz. J. Microbiol. 40, 879-883. the bacterial community to in-situ bioremediation of organic-rich sediments. Mar Pollut. Bull. 49, 740-751.

WHO (World Health Organization) (2011) Guidelines for drinking water quality. $4^{\text {th }}$ ed., WHO, Geneva.

Zhao, S., Hu, N., Chen, Z., Zhao, B., Liang, Y. (2009) Bioremediation of reclaimed wastewater used as landscape water by using the denitrifying bacterium Bacillus cereus. Bull. Environ. Contam. Toxicol. 83, 337-340.

Zahra, J.J., Amin, S.B., Akeel, H.A. (2014) Bacteriolytic activity of coliphages on diarrhea associated $E$. coli. Int. J. Nat. Sci. Res. 4, 69-75.

Vezzulli, L., Pruzzo, C., Fabiano M. (2004) Response of

$$
\begin{aligned}
& \text { تحسين معالجة مياه الصرف الصحي باستخدام أوراق الموز المجففة وكوكثيل من } \\
& \text { البكتيريوفاج } \\
& \text { نهي خالد الاجدج(1)، محمد عاطف نصر الدين(1)، محمد ابراهيم عزام(2)، ايه احمد محمد(1)، محمود محمد } \\
& \text { (1) هزاع } \\
& \text { (1)قتم النبات و الميكروبيولوجي ـ كلية العلوم - جامعة بنها ـ بنها ـ مصر ، (2)المعمل المركزى لمر اقبة الجودة } \\
& \text { البيئية ـ المركز القومي لبحوث المياه ـ القاهرةـ دصر. }
\end{aligned}
$$

\footnotetext{
بعد تلوث المباه مشكلة خطبرة ناتجة عن إدخال النفايات البيولوجية الخطرة و المو اد العضوية و المعادن الثقبلة في

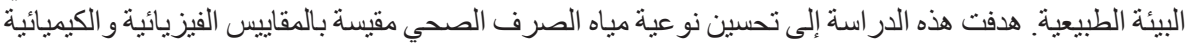

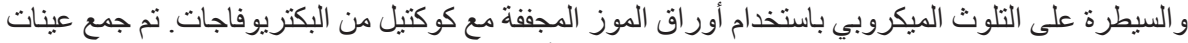

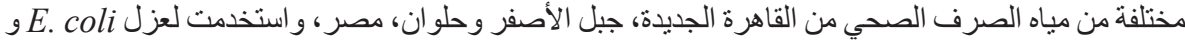

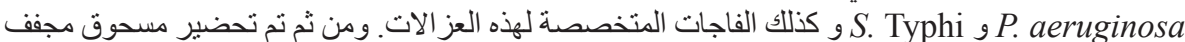

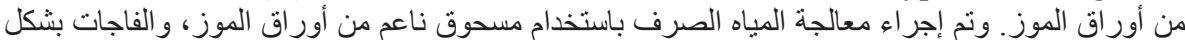

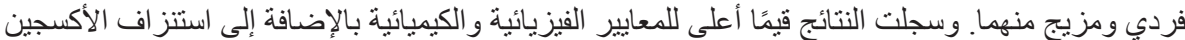

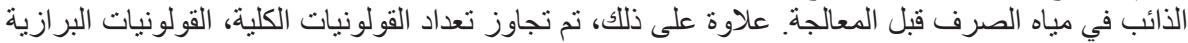

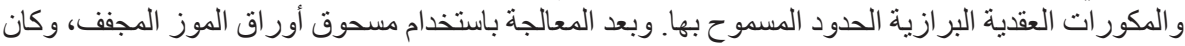

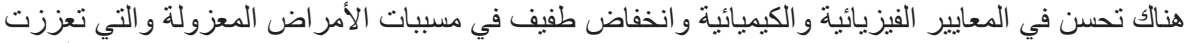

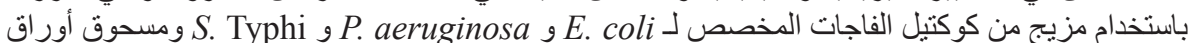

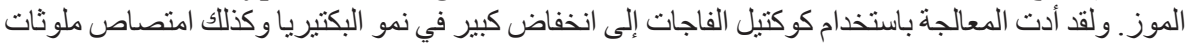

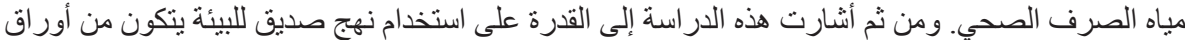

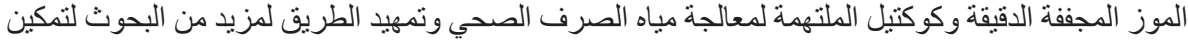

